\title{
Competitiveness Overview of Four Brazilian Non-timber Forest Products
}

\author{
Fernanda Costa $^{1}$, Diellen Lídia Rothbarth ${ }^{1}$, Jaqueline Valerius ${ }^{1}$, João Carlos Garzel Leodoro da Silva ${ }^{1}$, \\ Romano Timofeiczyk Júnior ${ }^{1}$, Pedro José Steiner Neto $^{2} \&$ José Roberto Frega $^{1}$ \\ ${ }^{1}$ Universidade Federal do Paraná, Curitiba, Brazil \\ ${ }^{2}$ Universidade Positivo, Curitiba, Brazil \\ Correspondence: Jaqueline Valerius, Universidade Federal do Paraná, Av. Prefeito Lothário Meissner, Curitiba, \\ Brazil. E-mail: jaquevalerius@gmail.com
}

Received: February 20, 2019

doi:10.5539/jas.v11n10p131
Accepted: May 30, 2019 Online Published: July 15, 2019

URL: https://doi.org/10.5539/jas.v11n10p131

\begin{abstract}
This study aimed to analyze the Brazilian competitiveness in the world market of the main non-timber forest products (NTFPs) exported by Brazil during the subperiods from 2006 to 2010, and from 2011 to 2016. The products were selected based on their relevance in the Brazilian NTFP export. In order to analyze competitiveness, we used the competitiveness matrix, which is given by the performance point of view. In the construction of this matrix, the vertical axis was represented by the Revealed Symmetric Comparative Advantage index while the horizontal axis was represented by the growth rate. The results showed that natural rubber was in the "missed opportunities" quadrant in the first period and in the "retreat" quadrant in the second period analyzed. On the other hand, honey, mate and cashew nut were positioned in the "optimum" sector in both periods, although cashew nut had showed a decrease both in the world growth rate and in the RSCA in the second period studied. In the final analysis, we concluded that Brazil is competitive in exports of honey and mate, it has been losing competitiveness in exports of cashew nuts, and is in decline as regards natural rubber exports.
\end{abstract}

Keywords: exports, competitiveness matrix, non-timber forest products, Brazil, markets

\section{Introduction}

Despite being known as one of the largest agricultural producers in the world, Brazil presents approximately $66.3 \%$ of its territory (632 million hectares) occupied by several forms of preserved native vegetation, which, by way of comparison, is equivalent to an area of 48 European countries. Moreover, it presents a variety of biomes with a huge diversity of non-timber forest products (NTFPs), presenting different characteristics and purposes: food, cosmetics, handicrafts, medicines, utilities, among others (FAO, 2015; Miranda, 2018).

Indeed, the extraction and trade of NTFPs in Brazil has a great social, economic and environmental importance as it contributes to preserve the biodiversity of native forests, generates income for producers who depend on these resources, and allows the maintenance of populations in their regions of origin. People living in the forest areas use their traditional knowledge to manage and extract these products without causing significant negative impacts on the forest, which contributes to the conservation of biodiversity and the generation of significant income for their subsistence. Important to realize that is also possibleto produce NTFPs in cultivated systems, and reach both international and domestic markets (Angelsen et al., 2004; Guariguata et al., 2017).

As an illustration, in 2016 the NTFPs were responsible for a turnover of R\$ 1.9 billion, in which $86.5 \%$ correspond to extractive activity in native forests, a 4.6\% increase compared to 2015. Even though Brazil exports a large number of NTFPs, there is little information available on their competitiveness in the international market. Although trade in NTFPs has been widely promoted as an approach to rural development, recent research indicates that commercialization of NTFPs is often unsuccessful (Marshall et al., 2003; SNIF, 2017).

Therefore, there is an urgent need to generate new information and tools to support decisions made by a broad range of stakeholders, including not only local communities, but also all actors involved in the commercialization of NTFPs. Notably, information is crucial to guide the products selection, how and where to invest, and the market potential of a certain product in a specific situation. By all means, Brazil has the potential to be one of the largest exporters of NTFPs, therefore, researches aiming to supply information about the 
behavior of this market and the critical factors to the competitiveness of its exports, provide a broad contribution to soften the barriers to trade development (Marshall et al., 2003; Schirigatti, 2014).

Despite a few studies on the NTFP market have been conducted in the past, neither of them has analyzed the competitiveness of the products together, in a way that could produce new and relevant information about them. Considering the importance of these products for the economic development of small rural producers, especially in the Amazon, it is indispensable that new market information on these products be brought to light.

For these reasons, the objective of this study was to analyze the Brazilian competitiveness in the world market of four main non-timber forest products exported by Brazil in the period from 2006 to 2016.

\section{Methods}

\subsection{Data Collection and Processing}

Data for this study were collected from two sources: the Foreign Trade Information Analysis System (Alice Web) developed by Brazilian Foreign Trade Secretariat and the Ministry of Development, currently replaced by the COMEXSTAT platform, and the United Nations Database on International Trade (UN Comtrade). The study covered the period from 2006 to 2016, aiming to analyze the value data of exports (US \$) and quantities ( $\mathrm{kg}$ ) of Cashew Nut, Mate, Rubber, and Honey.

Monetary values were deflated using the Consumer Price Index (CPI) base year 2016, collected from the United States Department of Agriculture's (USDA) website (2018). The 6-digit codes of each product, as defined by the Mercosul Common Nomenclature (NCM), used in this study were the following: Cashew nuts: 08.01.32; Companion: 09.03.00; Natural honey: 04.09.00; and Natural rubber: 40.01.10.

\subsection{Deflating Prices}

The methodology proposed by Mendes and Padilha Junior (2007), demonstrated in Equation 1, were used to correct monetary inflation. Parapinski (2012), Valerius (2016), Aguiar (2014), and Schirigatti (2014) also used this methodology in their research.

$$
\mathrm{RP}_{\mathrm{i}}=\mathrm{NP}_{\mathrm{i}} \times\left(\mathrm{CPI}_{2016} / \mathrm{CPI}_{\mathrm{i}}\right)
$$

Where, $\mathrm{RP}_{\mathrm{i}}=$ Real Price; $\mathrm{NP}_{\mathrm{i}}=$ Nominal Price; $\mathrm{CPI}_{2016}=$ Consumer Index Price for the base year; $\mathrm{CPI}_{\mathrm{i}}=$ Consumer Index Price for each period.

\subsection{Growth Rate}

To calculate the growth rate, we used the linear trend model proposed by Gujarati (2011) (Equation 2).

$$
\mathrm{Y}_{\mathrm{t}}=\mathrm{Y}_{0}(1+\mathrm{r})^{\mathrm{t}}
$$

Where, $Y_{t}=$ value or quantity over time $t ; Y_{0}=$ initial value or quantity; $r=$ compound or geometric growth rate; $\mathrm{t}=$ period.

The natural logarithm of Equation 1 is applied:

$$
\ln Y_{t}=\ln Y_{0}+t \cdot \ln (1+r)
$$

Where, $\ln =$ natural logarithm; $\mathrm{t}=$ time (years).

To obtain the instantaneous growth rate at time $t$, we used the log-linear model, in which only the regression is in logarithmic form (Equation 4) (Gujarati, 2011).

$$
\ln \mathrm{V}=\beta 1+\beta 2 \mathrm{t}+\mu \mathrm{t}
$$

Where, $\mathrm{LnV}=$ natural logarithm of exported value; $\beta 1=$ intercept; $\beta 2 \mathrm{t}=$ slope coefficient at time $\mathrm{t} ; \mu \mathrm{t}=$ error component.

The coefficient of trend variable in the growth model, indicated in Equation, 3 gives the instantaneous growth rate.

In order to obtain the composite growth rate, it is necessary to calculate the exponential coefficient $\beta 1$ (Equation 5) (Gujarati, 2011).

$$
r=\left[\left(\operatorname{Exp}^{\beta 1}-1\right) \times 100\right]
$$

Where, $\mathrm{r}=$ growth rate; $\operatorname{Exp}^{\beta 1}=$ exponential of $\beta 1$.

\subsection{Revealed Comparative Advantage Index}

Inspired by David Ricardo's comparative advantage law formulated in 1817, Balassa (1965) proposed an indicator to analyze revealed comparative advantage (RCAI). According to the author, international trade would 
show the comparative advantages of a country, but imports were massively affected by protectionist measures. For this reason, this author decided to develop an index containing only exports (Nonnenberg, 1995; Oliveira \& Schlindwein, 2015).

Therefore, the Revealed Comparative Advantage Index (RCAI) made possible to analyze the competitiveness from past information on trade flows. At the same time, it provides a measure of the relative structure of a region's exports: the larger the volume of a product exported by a region relative to the total exported volume of the same product, the greater the comparative advantage in the production of this product (Fernandes \& Viera Filho, 2000; Schirigatti, 2014).

The RCA in a region $\mathrm{j}$ for a product $\mathrm{i}$ can be defined as follows:

$$
\mathrm{RCA}_{\mathrm{ij}}=\left(\frac{\mathrm{x}_{\mathrm{ij}}}{\mathrm{x}_{\mathrm{iz}}}\right) /\left(\frac{\mathrm{x}_{\mathrm{j}}}{\mathrm{x}_{\mathrm{z}}}\right)
$$

Where, $X_{i j}=$ exports of product " $i$ " by country “ $j$ ”; $X_{i z}=$ world exports of the product " $i$ "; $X_{j}=$ Total exports from one specific country “ $\mathrm{j}$ ”; $\mathrm{X}_{\mathrm{z}}=$ total world exports.

In order to make matrices symmetrically, facilitating the visualization in graphs, Laursen and Engendal (1995) proposed the use of the Revealed Symmetric Comparative Advantage (RSCA), which varies from 0 to 1 : the closer to 1, the bigger the comparative advantage of product $i$ of country $\mathrm{j}$ is (Equation 7).

$$
\mathrm{RSCA}_{\mathrm{s}}=\frac{\mathrm{RCA}-1}{\mathrm{RCA}+1}
$$

Where, RSCA = Revealed Simetric Comparative Advantage Index; RCA = Revealed Comparative Advantage Index.

\subsection{The Competitiveness Matrix}

One way to determine a competitiveness of a country or sector is through the competitiveness matrix. By it means, changes in competitiveness are analyzed by assessing the relative dynamics of the market-shares of a country sectoral group in the total exports of a specific reference zone. Then, the results are plotted in a matrix that relates two variables: the evolution of the sectoral groups in the international market, and the competitive position of each group in the total exports of each country (Mandeng, 1991; Fajnzylberg, 1988; Xavier, 2001; Shmidt \& Bittencourt, 2010).

The vertical axis represents the competitiveness of a country or sector comparatively to other countries or sectors represented by the quantity exported, Revealed Comparative Advantage Index (RCA) or market share. On the other hand, the horizontal axis represents the dynamism of demand for the product under analysis given by export growth rate (Mandeng 1991) (Figure 1).

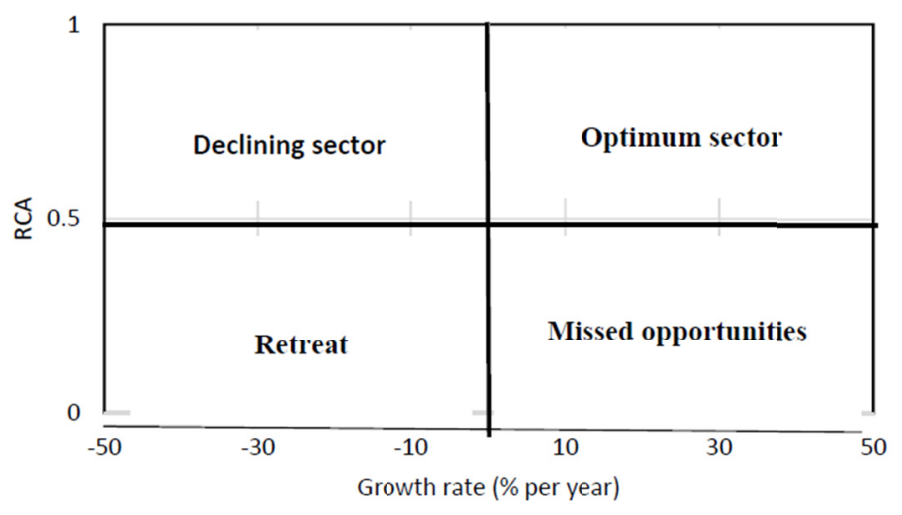

Figure 1. Competitiveness matrix

Source: Adapted from Mandeng (1991).

A country can improve its position by concentrating its exports in sectors with high demand, and then perpetuate its competitiveness in these sectors by maintaining or increasing its market gains (Barbosa Junior \& Pena, 2008; Costa, 2013). 
Thus, the competitiveness matrix distinguishes four quadrants, according to which export sectors, products or even countries can be classified: 1) Optimum sector ("Rising Stars"), 2) Declining sector, ("Waning Stars"), 3) Situation of missed opportunities ("Missed Opportunities") and 4) Situation of retreat ("Retreats").

If a product is in the optimum sector quadrante, it means that it is competitive, with an above average growth rate and is taking advantage of the market dynamism. The presence in the "declining sector" quadrant means that the dynamics of the sector are low and the product has grown more than the market average. Yet, the presence in "retreat sector" indicates that the product is growing less than the market average. Finally, the presence in the "Missed opportunities" quadrant indicates that the product is losing competitiveness in a market with high dynamism (Xavier, 2001).

\section{Results}

Figure 2 shows the positioning of the products analyzed in the competitiveness matrix in two subperiods. The subperiod 1 refers to the years 2006 to 2010, and the subperiod 2 refers to the positioning of the products between the years 2011 to 2016 .

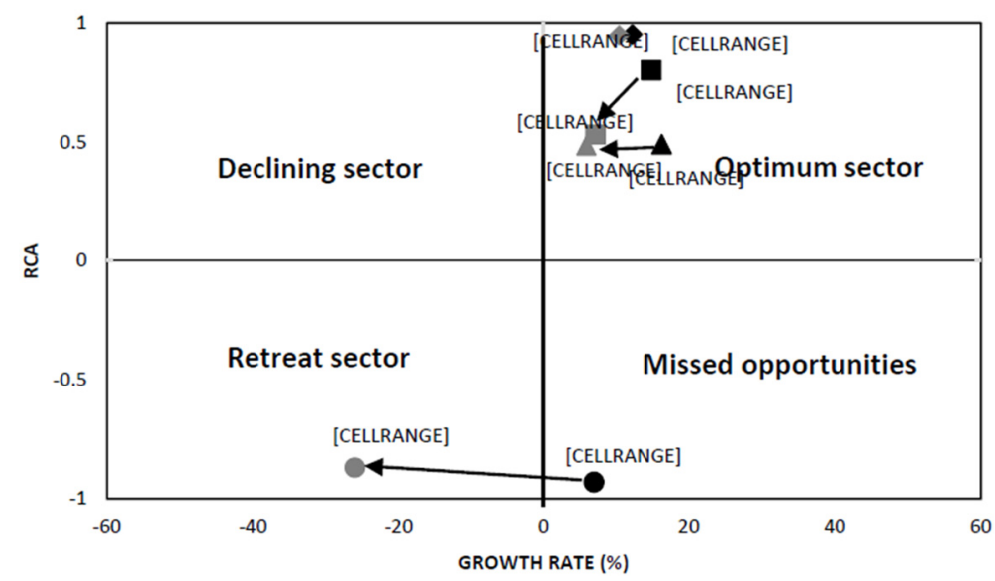

Figure 2. Competitiveness Matrix of Brazilian NTFPs during 2006-2016

Note. 1 = Position during the first sub period (2006-2010); 2 = position during the second sub period (2011-2016). $\mathbf{~}:$ Cashew Nut (CN); : Mate Herb (MH); $\mathbf{\wedge}$ : Natural Honey (NH); •: Natural Rubber (NR).

Table 2 shows the calculated RSCA and growth rate for each product in each subperiod. These values supported the elaboration of the competitiveness matrix (Figure 2).

Table 2. Growth rate and RSCA of the analyzed products

\begin{tabular}{lll}
\hline & Growth rate $(\%)$ & RSCA \\
\hline NR1 & 6.92 & -0.93 \\
CN1 & 14.82 & 0.80 \\
MH 1 & 12.19 & 0.95 \\
NH1 & 16.25 & 0.49 \\
NR2 & -26.01 & -0.87 \\
CN2 & 7.09 & 0.53 \\
MH2 & 10.40 & 0.95 \\
NH2 & 5.88 & 0.49 \\
\hline
\end{tabular}

\section{Discussion}

Among the four products analyzed, the only one not situated in the "optimum sector" quadrant in the first sub period studied (2006 to 2010) was natural rubber, situated instead in the "missed opportunities" sector. It means that the world product market grew, but Brazil lost its share (Figure 2), what is confirmed by the negative RSCA 
of 0.93. Regard the second sub period (2011 to 2016) (Figure 2), this product had an even worse dynamic, moving to the "retreat" quadrant with an RSCA of -0.87 (Table 2).

Important to realize that Brazil was already considered the main producer and exporter of natural rubber in the world in the late nineteenth and early twentieth centuries, however, it became an importer of this raw material from the early fifties (Nogueira et al., 2015).

In fact, Brazilian imports grew between 2006 and 2016, and Thailand was its largest supplier. Notably, Southeast Asia owns $90 \%$ of the world rubber production with the main producers being Malaysia, Thailand and Indonesia.

Motivated by the production costs higher than the prices of rubber from Asian countries, the Brazilian government created the "Rubber Law" in August 1997, which grants economic subsidies to rubber producers as a way of stimulating the Brazilian producer (Samonek, 2006). Unfortunately, it was not succeed due to the poor competitiveness of Brazilian natural rubber: besides its high cost of production, the lack of qualification and the rural exodus hampered the activity in the country (CIFlorestas, 2016).

These results corroborate the ideas of Nogueira et al. (2015), who observed that Brazil has an incomparably larger and adequate area for planting rubber trees compared to other world producing countries, but the production deficit results from the inexistence of public policies that actually support and protect national production, and investments applied in research and development.

These opinions, however, are subject to review. Since rural entrepreneurs can opt for the product that maximizes the objectives intended by them, including in partnerships with the industrial sectors, as it happens with other agroforestry products, then the existence of public policies to develop this sector is not necessarily a condition to its success.

Turning now to the cashew nuts, it was positioned in the "optimum sector" quadrant in the two sub periods analyzed (Figure 2), although it showed a decrease both in the world growth rate $(-53.16 \%)$ and in the RSCA $(-33.75 \%)$ (Table 2).

However, the decline in exports of cashew nuts is mostly explained by the lower productivity of the sector, caused in part by the shortage of water in recent years and by phytosanitary problems. All these facts turned a traditionally exporter sector in a substantial importer (Bulhões, 2016; CONAB, 2017; Figueiredo Filho, 2008).

Another key point in the cashew nuts exports decline was the US financial crisis in 2008. Notably, there was a shift in the destination of Brazilian exports, which were mainly directed to the US and since 2008 have turned to China (UN Comtrade, 2016).

Additionally, the crisis in the US market explains the fall in the growth rate of this product in the second sub period analyzed, since the United States is the world's largest consumer of this product, responsible for $34 \%$ of world imports (UN Comtrade, 2018).

Comparison of these findings with those of Marques et al. (2017) confirms that between 2007 and 2009, the destination market negatively influenced the performance of Brazilian exports of cashew nuts. During this period, although initiatives have been taken to modernize this export segment, uncertainty and instability in the external market inhibited investment and the ability to expand competitiveness.

Therefore, it is evident that the Brazilian cashew nut exporting segment requires reorganization in its destination markets, associate with investments in research and development to improve its competitiveness in the international market (Marques et al., 2017).

On the other hand, the Mate occupied the "optimum sector" in the two sub periods analyzed, characterized by a positive RSCA and world market growth, despite a fall in the growth rate of $14.68 \%$ between sub periods (Figure 1 and Table 2).

It must be highlighted that Brazil is the world's largest exporter of mate, totaling US \$83 million exported in 2016, even though the country competes directly with mate exported by Argentina, with these two countries holding $90 \%$ of mate traded in the world (UN Comtrade, 2016).

Finally, honey was also positioned in the "optimum sector" in the two analyzed sub periods, presenting a positive RSCA (Table 2), indicating that Brazil is competitive in exports of natural honey. The world market dynamics, although positive, showed a decrease of $-63.82 \%$ between the sub periods (2006-2010 and 2011-2016).

Brazil ranks 9th among the world's largest exporters of honey. In fact, in 2017, the country's exports grew $31.8 \%$ comparing to the previous year, and the United States was its main destination market, representing $86 \%$ of the 
honey exported by Brazil (MDIC, 2018). As an illustration, the largest exporters of honey in the period between 2010 and 2016 were China, New Zealand, and Argentina (ABEMel, 2018).

Indeed, Brazil became one of the largest exporters in the world in a short time because of its social, economic, and environmental characteristics, which enabled the development of beekeeping production (De Paula et al., 2016). However, Brazil has the potential to become one of the world leaders in the production of natural honey, given the quality its product and the country's production potential in terms of flora, climate and apicultural techniques (Freitas et al., 2004; Andrade, 2005).

Important to realize that this segment is developing organizational efforts and technical improvements in partnership with several public and private entities, conducting research to understand the properties of domestic honey. In essence, all these efforts aim to improve management techniques, strengthening the production chain as a whole and promoting the domestic and international commercialization of products derived from bees (ABEMel, 2018).

In the final analysis, the NWFPs represent a broad market segment with remarkable opportunities of growth, thanks to its versatility, variety of uses and differentiation of other commodities. However, they still lack research that solves their major obstacles to production, marketing, and value adding.

\section{Concluding Remarks}

$>$ In light of what has been presented, it is possible to conclude that Brazil is competitive in exports of honey and mate;

$>$ On the other hand, Brazilian cashew nuts have been losing competitiveness in the world market.

$>$ In addition, natural rubber exports had the worst performance, ranking in the "missed opportunities" quadrant in the first subperiod and in the "retreat" sector in the second subperiod;

$>$ It is necessary to invest in new technologies of processing and market strategies, especially for cashew nuts and natural rubber, so that these products become more competitive in the international market.

\section{References}

ABEMel (Associação Brasileira dos Exportadores de Mel). (2018). Retrieved from http://www.conap.coop.br/ wp-content/uploads/2017/01/INTELIG\%C3\%8ANCIAcomercial-abemel_dezembro-consolidado.pdf

Allegretti, M. (1992). Política de uso dos recursos naturais renováveis: Amazônia e o extrativismo. Revista Administração Pública, 1(26), 145-162.

Andrade, R. C. P. (2005). Apicultura-Mundo, Brasil, Paraná. Curitiba: Secretaria de Estado da Agricultura e do Abastecimento.

Angelsen, A., Jagger, P., Babigumira, R., Belcher, B., J. Hogarth, N., Bauch, S., ... Wunder, S. (2014). Environmental Income and Rural Livelihoods: A Global-Comparative Analysis. World Development, 64(1), S12-S28. https://doi.org/10.1016/j.worlddev.2014.03.006

Arnold, J. E. M., \& Pérez, M. R. (2001). Can non-timber forest products match tropical forest conservation and development objectives? Ecological Economics, 39(3), 437-447. https://doi.org/10.1016/S0921-8009(01) 00236-1

Balassa, B. (1965). Trade liberalization and 'revealed' comparative advantage. The Manchester School of Economic and Social Studies, 33(2), 99-123. https://doi.org/10.1111/j.1467-9957.1965.tb00050.x

Barbosa Junior, I. O., \& Pena, R. W. (2008). A. Análise comparativa dos produtos mais importantes e dinâmicos da pauta de exportação do Brasil e Coreia do Sul. Revista Lato \& Sensu, 9(2), 47-53.

Bonfatti Júnior, E. A., Lengowski, E. C., \& Ludka Júnior, A. (2018). Mapeamento do processo produtivo de erva-mate. Revista Internacional de Ciências, 8(1), 82-98. https://doi.org/10.12957/ric.2018.32500

Bulhões, A. (2016). Cajucultura potiguar cai de produção com envelhecimento das plantas, estiagem e pragas. Retrieved from http://nominuto.com/airtonbulhoes/cajucultura-potiguar-cai-de-producao-com-envelhecime nto-das-plantasestiagem-e-pragas/17593

CIFlorestas (Centro de Inteligência em Florestas). (2016). Mercados de produtos florestais alternam entre estagnação e crescimento nos seus diversos setores em 2016 (Conjunctural Analysis). Retrieved from http://www.ciflorestas.com.br/arquivos/a_n_2016_715709673.pdf 
CONAB (Companhia Nacional de Abastecimento). (2018). Histórico mensal castanha-de-caju. Retrieved from https:/www.conab.gov.br/info-agro/analises-do-mercado-agropecuario-e-extrativista/analises-do-mercado/h istorico-mensal-de-castanha-de-caju

Costa, T. R. A. (2013). Matriz de competitividade do setor florestal brasileiro no período de 1995 a 2011 (Masters Dissertation, Universidade Federal do Paraná, Curitiba, Paraná, Brasil).

Cruz, N. J. T., Silva, M. V. D., \& Moraes Filho, R. A. D. (2007). Consumo dos principais produtos derivados do caju e potencialidade dos produtos alternativos do caju na cidade de Maceió-Alagoas. Congresso da Sociedade Brasileira de Economia, Administração e Sociologia Rural. Retrieved from http://www.sober.org.br/palestra/6/874.pdf

De Figueirêdo Junior, H. S. (2008). Desafios para a cajucultura no Brasil: Análise de competitividade e recomendações para o setor. Revista Econômica do Nordeste, 39(3), 371-394.

De França Nogueira, R., Cordeiro, S. A., Leite, A. M. P., \& Da Silva Binoti, M. L. M. (2015). Mercado de borracha natural e viabilidade econômica do cultivo da seringueira no Brasil. Nativa, 3(2), 143-149. https://doi.org/10.14583/2318-7670.v03n02a12

De Morais, E. C., Stefanuto, A., Klein, G. A., Boaventura, B. C., De Andrade, F., Wazlawik, E., \& Da Silva, E. L. (2009). Consumption of Yerba Mate (Ilex paraguariensis) Improves Serum Lipid Parameters in Healthy Dyslipidemic Subjects and Provides an Additional LDL-Cholesterol Reduction in Individuals on Statin Therapy. Journal of Agricultural and Food Chemistry, 57(18), 8316-8324. https://doi.org/10.1021/ jf901660g

De Paula, M. F., Angelo, H., de Almeida, A. N., do Santos, A. J., \& da Silva, J. C. G. L. (2016). Mercado de mel natural: Competitividade nos preços de exportação. Revista Floresta, 46(3), 363-370. https://doi.org/ 10.5380/rf.v46i3.41009

Fajnzylber, F. (1988). Competitividade Internacional: Evolución y lecciones. Revista de la CEPAL, 36(1), 7-24. https://doi.org/10.18356/4630b47d-es

FAO (Food Agriculture and Organization). (2005). Global Forest Resources Assessment. Retrieved from http://www.fao.org/

FAO (Food and Agriculture Organization of the United Nations). (2014). Non-wood forest products: Who uses NWFPs and to whom are they important? Retrieved from //www.fao.org/forestry/nwfp/6388/en

FAO (Food and Agriculture Organization of the United Nations). (2015). Global Forest Resources Assessment. Retrieved from https://www.fao.org/3/a-i4808e.pdf

Fernandes, C. L. D. L., \&Vieira Filho, J. E. R. (2000). Especialização e competitividade de Minas Gerais no mercado internacional: Um estudo de indicadores de comércio exterior no período de 1992 a 1999. Seminário Sobre a Economia Mineira. Retrieved from http://www.cedeplar.ufmg.br/diamantina2000/textos/ candido.pdf

Fiedler, N. C., Soares, T. S., \& Silva, G. F. (2008). Produtos florestais não madeireiros: Importância e manejo sustentável da floresta. Revista Ciências Exatas e Naturais, 10(2), 263-278.

Freire, F. C. O., Cardoso, J. E., Dos Santos, A. A., \& Viana, F. M. P. (2002). Diseases of cashew nut plants (Anacardium occidentale L.) in Brazil. Crop Protection, 21(6), 489-494. https://doi.org/10.1016/ S0261-2194(01)00138-7

Freitas, D. G. F., Khan, A. S., \& Silva, L. M. R. (2004). Nível tecnológico e rentabilidade de produção de mel de abelha (Aplis melifera) no Ceará. Revista de Economia Rural, 42(1), 171-188. https://doi.org/10.1590/ S0103-20032004000100009

Giraldo, C. J. (2014). Viabilidade de Sistemas Produtivos De Borracha Natural na Amazônia: O Caso do Extrativismo na Resex Chico Mendes (Doctoral Thesis, Universidade Federal de Viçosa, Viçosa, Minas Gerais, Brasil).

Guariguata, M. R., Cronkleton, P., Duchelle, M. E., \& Zuidema, P. A. (2017). Revisiting the cornerstone of Amazonian conservation: A socioecological assessment of Brazil nut exploitation. Biodiversity and Conservation, 26(9), 2007-2027. https://doi.org/10.1007/s10531-017-1355-3

Gujarati, D. N., \& Porter, D. C. (2011). Econometria básica. São Paulo: McGraw Hill. 
Laursen, K., \& Engendal, C. (1995). The role of the technology factor in economic growth: A theoretical and empirical inquiry into new approaches to economic growth (Masters Dissertation, University of Aalborg, Aalborg, Denmark).

Mandeng, O. J. (1991). Competitividad internacional y especializacion. Revista de la CEPAL, 45. https://doi.org/ $10.18356 / 091 \mathrm{~b} 9 \mathrm{e} 1 \mathrm{e}-\mathrm{es}$

Marques, J. J. S., Araujo, J. M., Da Silva Lima, S., \& Reis, F. A. (2017). Competitividade das exportações brasileiras de castanha de caju e o efeito da crise de 2008. Ensaios FEE, 38(1), 135-162.

Marshall, E., Newton, A. C., \& Schreckenberg, K. (2003). Commercialisation of non-timber forest products: First steps in analysing the factors influencing success. International Forestry Review, 5(2), 128-137. https://doi.org/10.1505/IFOR.5.2.128.17410

Martin, N. B., \& Arruda, S. T. A. (1993). Produção brasileira de borracha natural: Situação atual e perspectivas. Informações Econômicas, 23(09), 9-55.

Mendonça, T., Lírio, V., Gomes, M., \& Campos, A. (2009). Inserção do Brasil no Mercado Mundial de Castanha de Caju no Período de 1990 a 2005. Revista Econômica do Nordeste, 40(1), 133-151.

Miranda, E. E. (2018). Agricultura e Preservação Ambiental: Uma análise do Cadastro Ambiental Rural. Campinas: Embrapa Territorial. Retrieved from https://www.cnpm.embrapa.br/projetos/car/estados/SP/ sp_micro.html

Murakami, A. N. N., Amboni, R. D. D. M. C., Prudêncio, E. S., Amante, E. R., Fritzen-Freire, C. B., ... Maraschin, M. (2013). Concentration of biologically active compounds extracted from Ilex paraguariensis St. Hil. by nanofiltration. Food Chemistry, 141(1), 60-65. https://doi.org/10.1016/j.foodchem.2013.02.119

Nonnemberg, M. J. B. (1995). Vantagens comparativas reveladas, custo relativo de fatores e intensidades de recursos naturais: Resultados para o Brasil 1980-88. Instituto de Pesquisa e Planejamento Econômico, 25(2), 7-24.

Oliveira, M. D. F., \& Schlindwein, M. (2015). Índice de Vantagem Comparativa Revelada do Complexo Soja da Região Centro-Oeste Brasileira. Revista de Estudos Sociais, 17(33), 109-131. https://doi.org/10.19093/ res.v17i33.2365

Oliveira, V. H. D. (2008). Cajucultura. Revista Brasileira de Fruticultura, 30(1), 1-3. https://doi.org/10.1590/ S0100-29452008000100001

Paula Neto, F. L., \& Almeida Neto, R. M. (2005). Principais mercados apicolas mundiais e a apicultura brasileira. Congresso da Sociedade Brasileira de Economia de Sociologia.

Paula, M. F., dos Santos, A. J., da Silva, J. C. G. L., Junior, R. T., \& Hoeflich, V. A. (2015). Dinâmica das Exportações de Mel Natural Brasileiro no Período de 2000 a 2011. Floresta e Ambiente, 22(2), 231-238. https://doi.org/10.1590/2179-8087.062713

Pena, H. W. A (2005). Brasil e Coréia do Sul: uma análise comparativa da dinâmica das exportações no comércio internacional, 1985-2000 (Masters Dissertation, Universidade da Amazônia, Pará, Brazil).

Pereira, J.P., Doretto, M., Leal, A. C., Castro, A. M. G., \& Rucker, N. A. L. (2000). Cadeia produtiva da borracha natural: Análise diagnóstica e demandas atuais no Paraná. Londrina: IAPAR.

Plese, N. G. D. S. P. (2017). Avaliação da efetividade local de políticas públicas de fomento ao extrativismo de PFNM no Acre: o caso da RESEX do Cazumbá-Iracema (Masters Dissertation, Instituto Nacional de Pesquisas da Amazônia, Pará, Brazil).

Samonek, F. (2006). A borracha vegetal extrativa na Amazônia: Um estudo de caso dos novos encauchados de vegetais no Estado do Acre (Masters Dissertation, Universidade Federal do Acre, Acre, Brazil).

Schirigatti, E. L. (2014). Dinâmica das exportações e avaliação da competitividade do setor de mate brasileiro (Masters Dissertation, Universidade Federal do Paraná, Paraná, Brasil).

Schmidt, R., \& Bittencourt, M. V. L. (2010). O perfil tecnológico das exportações brasileiras: Uma análise prospectiva para o período 1985-2004. Revista Economia \& Tecnologia, 22(06), 157-172. https://doi.org/ 10.5380/ret.v6i3.26964

SEBRAE (Serviço Brasileiro de Apoio às Micro e Pequenas Empresas). (2006). Desafios da apicultura brasileira. Revista SEBRAE Agronegócios, 3, 1-64. 
Shanley, P., Pierce, A. R., Laird, S. A., Binnqüist, C. L., Guariguata, M. R. (2014). From Lifelines to Livelihoods: Non-timber Forest Products into the Twenty-First Century. Tropical Forestry Handbook (pp. 1-50). https://doi.org/10.1007/978-3-642-41554-8_209-1

SNIF (Sistema Nacional de Informações Florestais). (2017). Florestas no Brasil (Boletim 2017). Retrieved from http:/www.florestal.gov.br/documentos/publicacoes/3230-boletim-snif-2017-ed1-final

Sousa, F. F. D., Vieira Da Silva, C., \& Barros, F. B. (2018). The (in)visible market of miriti (Mauritia flexuosa L.f.) fruits, the "winter acai", in Amazonian riverine communities of Abaetetuba, Northern Brazil. Global Ecology and Conservation, 14, 1-12. https://doi.org/10.1016/j.gecco.2018.e00393

UN Comtrade (United Nations Commodity Trade Statistics Database). (2018). Export dynamics of non-timber products. Retrieved from https://comtrade.un.org

Venkattakumar, R. (2009). Socio-economic factors for cashew production and implicative strategies: An overview. Indian Research Journal, 9(3), 55-62.

Xavier, C. L. (2001). Padrões de especialização e saldos comerciais no Brasil. Congresso da Sociedade Brasileira de Economia, Administração e Sociologia Rural. Retrieved from http://www.anpec.org.br/ encontro2001/artigos/200103253.pdf

\section{Copyrights}

Copyright for this article is retained by the author(s), with first publication rights granted to the journal.

This is an open-access article distributed under the terms and conditions of the Creative Commons Attribution license (http://creativecommons.org/licenses/by/4.0/). 